\title{
Use of Medicinal Plants with Teratogenic and Abortive Effects by Pregnant Women in a City in Northeastern Brazil
}

\section{Uso de Plantas Medicinais com Efeitos Teratogênicos e Abortivos por Gestantes em uma Cidade no Nordeste do Brasil}

\author{
Cristina Ruan Ferreira de Araújo ${ }^{1}$ Felipe Gomes Santiago ${ }^{2}$ Marcelo Italiano Peixoto ${ }^{2}$ \\ José Olivandro Duarte de Oliveira ${ }^{2}$ Mayrla de Sousa Coutinho ${ }^{3}$ \\ 1 Tutorial EducationProgramGroup / Conexão de Saberes, \\ Department of Health Sciences, Universidade Federal de Campina \\ Grande - UFCG, Campina Grande, PB, Brazil \\ 2 Medical School, UFCG, Campina Grande, PB, Brazil \\ 3 Undergraduate Nursing Course, UFCG, Campina Grande, PB, Brazil \\ Address for correspondence Cristina Ruan Ferreira de Araújo, MD, \\ PhD, Department of Health Sciences, Universidade Federal de \\ Campina Grande - UFCG, Av. Juvêncio Arruda, 795 - Bodocongó, \\ Campina Grande, PB, Brazil 58431-040 \\ (e-mail: profcristinaruan@gmail.com).
}

Rev Bras Ginecol Obstet 2016;38:127-131.

\section{Abstract \\ Keywords \\ - phytotherapy \\ - pregnancy \\ - medicinal plants \\ - peumus boldus \\ - foeniculum vulgare \\ - melissa officinalis}

\section{Resumo}

Purpose The purpose of this study is to verify the use of medicinal plants by pregnant women treated at four Basic Health Units and at a public maternity facility in Brazil's northeast.

Methods This is a cross-sectional, quantitative study, performed between February and April 2014. The subjects were 178 pregnant women, aged 18 to 42 years. To collect data, a structured questionnaire with dichotomous and multiple choice questions was used. To verify the correlation between the variables, Pearson's chi-square test was used.

Results The study showed that $30.9 \%$ of the pregnant women used medicinal plants, and boldo was the most cited (35.4\%). All the plants utilized, except lemongrass, have toxic effects in pregnancy, according to Resolution SES/RJ N ${ }^{\circ} 1757$. There was no statistically significant correlation between social class and use of medicinal plants. Conclusion The health of the study participants and their unborn children is at risk due to the inappropriate use of medicinal plants.

Objetivo Verificar o perfil de uso de plantas medicinais por gestantes atendidas em quatro Unidades Básicas de Saúde da Família e em uma maternidade pública da cidade de Campina Grande - PB, na região Nordeste do Brasil.

Métodos Estudo transversal, quantitativo, desenvolvido no período de Fevereiro a Abril de 2014. Foi incluída uma amostra com 178 gestantes com idade entre 18 e 42 anos. O instrumento de coleta foi um questionário estruturado com perguntas received August 18, 2015 accepted December 1, 2015 published online March 21, 2016
DOI http://dx.doi.org/ 10.1055/s-0036-1580714. ISSN 0100-7203.
Copyright $@ 2016$ by Thieme Publicações License terms

Ltda, Rio de Janeiro, Brazil 
Palavras-chave

- fitorerapia

- gravidez

- plantas medicinais

- peumus boldus

- foeniculum vulgare

- melissa officinalis dicotômicas e de múltipla escolha. Para verificar a associação entre as variáveis estudadas, utilizou-se o teste Qui-quadrado de Pearson.

Resultados Foi constatado que $30,9 \%$ das gestantes utilizavam plantas medicinais, sendo o boldo a mais citada (35,4\%). Entre as plantas utilizadas com alta frequência pelas gestantes, todas, com exceção apenas da Erva-Cidreira (Melissa officinalis), apresentavam possíveis efeitos tóxicos para a gestação, segundo a Resolução SES/RJ N ${ }^{\circ}$ 1757. Ao comparar a classe social e o uso de plantas medicinais, não observou-se relação significante.

Conclusões A saúde das grávidas que fazem uso de plantas consideradas medicinais, assim como a de seus filhos, sofrem riscos devido ao uso inadequado destas plantas.

\section{Introduction}

Phytotherapy is defined as therapy based on the use of medicinal plants. The use of these plants for treatment, cure, and prevention of diseases has mostly originated from popular knowledge derived from ancient cultures. ${ }^{1}$ This traditional knowledge of medicinal plants has been used by the pharmaceutical industry, as there is enormous potential for the discovery of new drugs. ${ }^{2}$

According to the declaration of Alma-Ata in 1978, the World Health Organization (WHO) recognizes that $80 \%$ of the population in developing countries - including Brazil - use traditional practices in their basic healthcare, and $85 \%$ use medicinal plants, or preparations from them. Accordingly, it is the intention of the WHO to encourage the use of phytotherapy in basic healthcare. ${ }^{3}$

As the use of medicinal plants is based mostly on cultural heritage and not in research on their effects, it is necessary to study how they are used by the populace. Knowledge acquired from cultural heritage can lead to the inappropriate use of plants, with adverse reactions in certain situations. ${ }^{4}$

Pregnant women may turn to this therapeutic option and require special attention. Because many allopathic medicines are teratogenic and are contraindicated during pregnancy, women may seek phytotherapy as alternative care. ${ }^{5}$

Medicinal plants have a globally important role during pregnancy, birth, and the postpartum period. The use of plants before and after delivery and during lactation has been documented in various cultures. However, the majority of research focuses on the knowledge of these plants held by male folk healers, shamans, or others, neglecting the knowledge possessed by women themselves. ${ }^{6}$

Nonetheless, studies indicate that some medicinal plants have toxic, teratogenic, and abortive potential, because some active principles are able to cross the placental barrier and reach the fetus, especially in the first trimester of pregnancy. Studies performed with plants commonly used by the populace, such as the babosa (Aloe spp. L.), peppermint (Mentha piperita $\mathrm{L}$ ), fennel (Foeniculum vulgare Mill.), and carqueja (Baccharistrimera (Less.) DC.), among others, are contraindicated in pregnant women. ${ }^{7}$

The Secretary of Health of the State of Rio de Janeiro published Resolution SES/RJ No. 1757 on February 18, 2008, contraindicating various medicinal plants on the basis of scientific studies that revealed the hazards they represent for the baby, both during gestation and breastfeeding.

The objective of this study was to identify which medicinal plants are used by pregnant women attending a Central Unit and four Basic Family Health Units in the city of Campina Grande in the northeast of Brazil.

\section{Methods}

This cross-sectional study with a quantitative design was developed at the Elpídio de Almeida Health Institute (ISEA) located in the central district, and in four Basic Family Health Units (UBSF) of the Malvinas borough (Malvinas I, II, III, and IV), in Campina Grande - PB, from February to April 2014.

A total of 178 pregnant women over 18 years of age participated in the research, in any stage of pregnancy. They attended the ISEA and Basic Family Health Units of the Malvinas borough, and gave informed consent, based on the guidelines and regulatory standards for research involving human beings covered by the Resolution 196/96 of the National Health Council.

The research team used a structured questionnaire to gather data. ${ }^{5}$ The first part consisted of questions regarding demographic and socioeconomic status; the second part included questions regarding general knowledge about medicinal plants; the third part questioned specific knowledge, such as indications for use of certain plants, and the method of preparation, among others. The plants cited by pregnant women were compared with those in Resolution SES/RJ N ${ }^{\circ}$ 1757, which contraindicated the use of certain plants during pregnancy.

The researchers used SPSS (SPSS Inc., Chicago, USA) Version 17.0 to organize the database and for statistical analysis. To verify the association between the variables studied (use of plants as a dependent variable and social class as an independent variable), we used Pearson's non-parametric Chi-square test, with a significance level of $p<0.05$ and a $95 \%$ confidence interval. The social classification of the population was based on the economic criteria of the Brazilian Association of Research Companies (Associação Brasileira de Empresas de Pesquisa - ABEP). 
Table 1 Socioeconomic profile of pregnant women attending the Elpídio de Almeida Health Institute and the Basic Family Health Units of the neighborhood of Malvina in Campina Grande, PB, Brazil, from February to April 2014

\begin{tabular}{|l|l|l|l|l|l|}
\hline Characteristics & $\mathbf{n}$ & $\%$ & Characteristics & $\mathbf{n}$ & $\%$ \\
\hline Marital status & & & Salary Range & & \\
\hline Married & 117 & 65.7 & Up to 1 M.W. & 91 & 51.1 \\
\hline Single & 58 & 32.6 & 1 to 2 M.W. & 64 & 36 \\
\hline Stable Relationship & 2 & 1.1 & 2 to 3 M.W. & 13 & 7.3 \\
\hline Divorced & 1 & 0.6 & More than 3 M.W. & 10 & 5.6 \\
\hline Education & & & Social Class & & \\
\hline High School complete & 79 & 44.4 & C2 & 56 & 31.4 \\
\hline Elementary incomplete & 45 & 25.3 & C1 & 55 & 30.8 \\
\hline Elementary Complete & 37 & 20.8 & D & 44 & 24.7 \\
\hline Higher education complete & 9 & 5.1 & B2 & 17 & 9.5 \\
\hline Illiterate & 3 & 1.7 & E & 3 & 1.6 \\
\hline High School Incomplete & 3 & 1.7 & B1 & 3 & 1.6 \\
\hline Higher education Incomplete & 2 & 1.1 & - & - & - \\
\hline
\end{tabular}

Abbreviation: M.W., Minimum Wage.

The research project was approved by the Research Ethics Committee of the Hospital UniversitárioAlcidesCarneiro, under protocol number 05552412.0.1001.5182 in 2013.

\section{Results}

Of the 178 pregnant women interviewed, $48.8 \%$ were 26 to 35 years old. Their ages ranged from 18 to 42 years, with a mean age of 28 . Among the participants, $65.7 \%$ were married and $44.4 \%$ had completed an elementary school education. The predominant social class was C2 (31.4\%), with a family income of up to one minimum wage (51.1\%). These data are shown in - Table 1. A total $47.2 \%$ were in the third trimester, $34.8 \%$ in the second, and $18 \%$ in the first. Conventional houses were occupied by $84.8 \%$, and $80.3 \%$ had access to basic sanitation.

During pregnancy, 30.9\% reported the use of medicinal plants. The most used plants were boldo (Peumusboldus Molina, by $35.4 \%$ ), Fennel (Foeniculum vulgare, by $24.2 \%$ ), balm mint (Melissa officinalis L., by 22.5\%), lemongrass (Cymbopogoncitratus (DC.) Stapf, by 6.4\%), chamomile (Matricariachamomilla L., by $4.8 \%$ ), carqueja (B. trimera, by $3.2 \%$ ), and mint (M. piperita, by $3.2 \%$ ). The data for each of these plants are summarized in - Table 2.

There was no statistically significant correlation between social class and the use of medicinal plants $(p=0.8)$. Of the women in the first trimester of pregnancy, $21.9 \%$ used medicinal plants, as did $33.9 \%$ in the second trimester, and $32.1 \%$ in the third trimester.

The participants reported that knowledge on the use of medicinal plants had been acquired from relatives (89.3\%), friends (5.1\%), books (2.2\%), physicians $(0.6 \%)$, and others (1.7\%). Relatives were the most responsible for the use of plants $(81.8 \%)$, while health professionals were responsible for only $2.6 \%$ of recommendations.
The plants were acquired mostly by purchase (67.5\%) or were home-grown (19.5\%), and were used typically once a day (36.6\%), boiled (54.6\%), and used daily (55.5\%). Among interviewees who used medicinal plants to treat discomfort related to pregnancy (12.9\%), the most common symptoms were nausea $(47 \%)$, pain in general $(29.4 \%)$, and heartburn (11.8\%).

A total $73.6 \%$ said they believed that the use of certain medicinal plants can cause adverse effect in pregnancy. Among those who said they perceived an undesirable effect (3.6\%), the most frequently mentioned were bleeding (1.8\%), allergy $(0.9 \%)$, and headache $(0.9 \%)$.

\section{Discussion}

Pregnancy is considered special, both scientifically and culturally. Thus, certain practices based in both biomedical and popular knowledge are seen in pregnant women. ${ }^{8}$ The use of medicinal plants is one example.

The concern about harm to the fetus leads some pregnant women to avoid allopathic medicines and choose medicinal plants, which are perceived as natural and, therefore, unable to cause harm. This raises concerns about the possible effects that their indiscriminate use may cause. ${ }^{9}$

In the present study, $30.9 \%$ of the pregnant women used medicinal plants. In a study by Macena et al, ${ }^{10} 55.5 \%$ of pregnant women reported using medicinal plants.

We found no significant relationship $(p=0.8)$ between the use of plants and social class. Therefore, the indiscriminate use of phytotherapy extends across all segments of the population, confirming studies by Veiga Júnior, ${ }^{11}$ which highlight indiscriminate self-medication with medicinal plants by all social classes.

It is known that the first trimester of pregnancy is the period of embryonic differentiation. At this stage, there is 
Table 2 List of plants most used by pregnant women in this study

\begin{tabular}{|c|c|c|c|c|}
\hline Popular name & Scientific name & $\%$ of use & Indication & Adverse Effects \\
\hline Boldo & Peumus boldus & 35.4 & $\begin{array}{l}\text { Ability to protect the liver } \\
\text { from toxins (hepatoprotec- } \\
\text { tive) due to the antioxidant } \\
\text { activity of its active ingredi- } \\
\text { ent, }{ }^{15,16} \text { boldine, which is also } \\
\text { an agent potentially useful in } \\
\text { the treatment of breast } \\
\text { cancer. }{ }^{17}\end{array}$ & $\begin{array}{l}\text { Teratogenic effects and } \\
\text { abortifacient. } 18\end{array}$ \\
\hline Fennel & Foeniculum vulgare & 24.2 & $\begin{array}{l}\text { Carminative, expectorant, } \\
\text { spasmolytic, and diuretic } \\
\text { action. }\end{array}$ & $\begin{array}{l}\text { Hydroalcoholic extracts } \\
\text { caused effects on embryo im- } \\
\text { plantation. Teratogenic po- } \\
\text { tential should be } \\
\text { considered. }{ }^{20} \text { Abortifacient } \\
\text { and galactogogue activity. }\end{array}$ \\
\hline Balm mint & Melissa officinalis & 22.5 & $\begin{array}{l}\text { Reduces the duration and in- } \\
\text { tensity of herpes outbreaks } \\
\text { due to antiviral properties. } \\
\text { Sedative and anxiolytic } \\
\text { effects. }\end{array}$ & $\begin{array}{l}\text { Abortifacient or teratogenic } \\
\text { effects were not found in the } \\
\text { literature consulted. }\end{array}$ \\
\hline Lemon Grass & Cymbopogon citratus & 6.4 & $\begin{array}{l}\text { Sedative, anti-inflammatory, }{ }^{24} \\
\text { gastroprotective, }{ }^{25} \text { and anti- } \\
\text { allergic action. }\end{array}$ & $\begin{array}{l}\text { Relaxing property for the } \\
\text { uterine musculature. }\end{array}$ \\
\hline Chamomile & Matricaria chamomilla & 4.8 & $\begin{array}{l}\text { Moderate antimicrobial and } \\
\text { antioxidant property and } \\
\text { powerful anti-inflammatory } \\
\text { activity. }{ }^{27}\end{array}$ & $\begin{array}{l}\text { Has emmenagogue } \\
\text { properties. }\end{array}$ \\
\hline Carqueja & Baccharis trimera & 3.2 & $\begin{array}{l}\text { Cytoprotective of the gastric } \\
\text { mucosa, capable of inhibiting } \\
\text { ulcers. }{ }^{29} \text { Has relevant hyper- } \\
\text { glycemic effect. }{ }^{30} \text { Hepatopro- } \\
\text { tective, anti-inflammatory, } \\
\text { and cholagogue activity, re- } \\
\text { lated to the presence of } \\
\text { flavonoids. }{ }^{31,32}\end{array}$ & $\begin{array}{l}\text { Induction of abortion due its } \\
\text { uterotonic properties. } 7,33\end{array}$ \\
\hline Mint & Mentha piperita $L$. & 3.2 & $\begin{array}{l}\text { It has shown promising activi- } \\
\text { ty in the treatment of intesti- } \\
\text { nal spasms. }\end{array}$ & $\begin{array}{l}\text { Emmenagogue and terato- } \\
\text { genic }^{7} \text {; cytotoxic. }\end{array}$ \\
\hline
\end{tabular}

greater risk of congenital malformations due to exposure to certain substances. In the present study, $21.9 \%$ of pregnant women used medicinal plants in the first trimester, and their fetuses were, thus, more vulnerable to the risk of malformations. During the second and third trimesters, changes due to exposure to toxic substances may also occur, affecting growth and functional development. ${ }^{12}$

The majority of the pregnant women (84.8\%) lived in conventional houses, which contributes to the use of home-grown medicinal plants.

The method by which women learned about the plants was similar to that reported in the study by Veiga Junior ${ }^{11}$ : $90.1 \%$ of the interviewees obtained knowledge about such therapy from family members or friends, and only $3.2 \%$ from a medical recommendation. These data confirm that the origin of knowledge on medicinal plants is mostly of sociocultural origin, rather than from prior studies on the effects of such treatment. ${ }^{3}$ During pregnancy, women become more susceptible to advice and guidance from family and friends on home remedies considered beneficial, thereby facilitating self-medication. $^{13}$

Self-medication is a practice in which a patient gets or produces and uses a product, be it a synthetic drug or a medicinal plant, without the guidance of a qualified professional. When used by pregnant women, such medication presents a risk to the health of both mother and fetus. One must emphasize the need for guidance by health professionals (in this study, they were responsible for only $2.6 \%$ of phytotherapy recommendations), grounded in the scientific study of medicinal plants. ${ }^{12}$

The most consumed plant species were boldo(P. boldus) (35.4\%), Fennel (Foeniculum vulgare) (24.2\%), balm mint ( $M$. officinalis) (22.5\%), lemongrass (C. citratus) (6.4\%), chamomile (M. chamomilla) (4.8\%), carqueja(B. trimera) (3.2\%), and mint (Mentha piperita L.) (3.2\%). In a study of the use of medicinal plants by pregnant women, ${ }^{13}$ the most cited were balm mint (79.5\%), boldo (41\%), and anise (28\%). In the study performed by Veiga Júnior, ${ }^{11}$ boldo was also the most cited 
plant (14.7\%). In another study on the use of medicinal plants by pregnant women, the most used were boldo (35.2\%), lemongrass (21.5\%), and mint (15.6\%). ${ }^{10}$

In a comparison of the plants most used by pregnant women with those contraindicated during pregnancy, based on Resolution SES/RJ No. 175714, six of the seven most cited plants are listed. Thus, there is a clear need to establish safety criteria for the use of medicinal plants during pregnancy. These criteria should take into account studies on the toxicity of phytotherapeutic products in pregnancy, including their actions on the fetus, and the possible adverse effects on the mother.

\section{References}

1 Albuquerque UP, Hanazaki N. As pesquisas etnodirigidas na descoberta de novos fármacos de interesse médico e farmacêutico: fragilidades e perspectivas. Rev Bras Farmacogn. 2006;16 (Supl):678-689

2 Sharma V, Sarkar IN. Bioinformatics opportunities for identification and study of medicinal plants. BriefBioinform 2013;14(2): $238-250$

3 da Rosa C, Câmara SG, Béria JU. Representations and use intention of phytotherapy in primary health care. CienSaudeColet 2011; 16(1):311-318

4 Bochner R, Fiszon JT, Assis MA, Avelar KES. Problemas associados ao uso de plantas medicinais comercializadas no Mercadão de Madureira, município do Rio de Janeiro, Brasil. RevBras Plantas Med. 2012;14(3):537-547

5 Faria PG, Ayres A, Alvim NAT. O diálogo com gestantes sobre plantas medicinais: contribuições para os cuidados básicos de saúde. ActaSci Health Sci. 2004;26(2):287-294

6 Lamxay V, de Boer HJ, Björk L. Traditions and plant use during pregnancy, childbirth and postpartum recovery by the Kry ethnic group in Lao PDR. J EthnobiolEthnomed 2011;7:14

7 Alonso J. Tratado de fitomedicina: bases clínicas y farmacológicas. Buenos Aires: ISIS Ediciones SRL; 1998

8 Calvasina PG, Nations MK, Jorge MSB, Sampaio HAC. "Birth weakness": cultural meanings of maternal impressions for infant health in Northeast Brazil. Cad SaudePublica 2007;23(2): 371-380

9 Louik C, Gardiner P, Kelley K, Mitchell AA. Use of herbal treatments in pregnancy. Am J ObstetGynecol 2010;202(5):439. e1-439.e10

10 Macena LM, Nascimento ASS, Krambeck K, Silva FA. Plantas medicinais utilizadas por gestantes atendidas na unidade de saúde da família (USF) do Bairro Cohab Tarumã no Município de Tangará da Serra, Mato Grosso. BioFar. 2012;7(1):143-155

11 Veiga Junior VF. Estudo do consumo de plantas medicinais na Região Centro-Norte do Estado do Rio de Janeiro: aceitação pelos profissionais de saúde e modo de uso pela população. RevBrasFarmacogn. 2008;18(2):308-313

12 Carmo TA, Nitrini SMOO. Drug prescription for pregnant women: a pharmacoepidemiological study. CadSaude Publica 2004;20(4): 1004-1013

13 Rangel M, Bragança FCR. Representações de gestantes sobre o uso de plantas medicinais. RevBras Plantas Med. 2009;11(1):100-109

14 Rio de Janeiro. Secretaria de Estado de Saúde. Resolução SES/RJ n. 1757, de 18 de fevereiro de 2002. Contra-indica o uso de plantas medicinais no âmbito do Estado do Rio de Janeiro e dá outras providências. Diário Oficial do Estado do Rio de Janeiro, 2002 Feb 20

15 Fernández J, Lagos P, Rivera P, Zamorano-Ponce E. Effectof boldo (Peumus boldus Molina) infusiononlipoperoxidationinducedbycisplatin in miceliver. Phytother Res 2009;23(7):1024-1027
16 Muñoz-Velázquez EE, Rivas-Díaz K, Loarca-Piña MGF, MendozaDíaz S, Reynoso-Camacho R, Ramos-Gómez M. Comparacióndelcontenido fenólico, capacidad antioxidante y actividadantiinflamatoria de infusionesherbalescomerciales. Rev Mex CiencAgríc. 2012;3(3):481-495

17 Paydar M, Kamalidehghan B, Wong YL, Wong WF, Looi CY, Mustafa MR. Evaluation of cytotoxic and chemotherapeutic properties of boldine in breast cancer using in vitro and in vivo models. Drug Des DevelTher 2014;8:719-733

18 Almeida ER, Melo AM, Xavier H. Toxicological evaluation of the hydro-alcohol extract of the dry leaves of Peumus boldus and boldine in rats. Phytother Res 2000;14(2):99-102

19 Araujo RO, Souza IA, Sena KXFR, Brondani DJ, Solidônio EG. Avaliação biológica de Foeniculum vulgare (Mill.) (Umbelliferae/Apiaceae). RevBras Plantas Med. 2013;15(2):257-263

20 Barilli SLS, Pereira MSL, Foscarini PT, Silva FC, Montanari T. An experimental investigation on effect of Foeniculum vulgare Mill. on gestation. Reprod Clim. 2012;27(2):73-78

21 Newall CA, Anderson LA, Phillipson JD. Plantas medicinais: guia para profissional de saúde. RibeirãoPreto: Editorial Premier; 2002

22 Astani A, Navid MH, Schnitzler P. Attachment and penetration of acyclovir-resistant herpes simplex virus are inhibited by Melissa officinalis extract. Phytother Res 2014;28(10):1547-1552

23 Kennedy DO, Little W, Scholey AB. Attenuation of laboratoryinduced stress in humans after acute administration of Melissa officinalis (Lemon Balm). Psychosom Med 2004;66(4):607-613

24 Avoseh O, Oyedeji O, Rungqu P, Nkeh-Chungag B, Oyedeji A. Cymbopogon species; ethnopharmacology, phytochemistry and the pharmacological importance. Molecules 2015;20(5): 7438-7453

25 Sagradas J, Costa G, Figueirinha A, et al. Gastroprotective effect of Cymbopogoncitratus infusion on acute ethanol-induced gastric lesions in rats. J Ethnopharmacol 2015;173:134-138

26 Santos Serafim Machado M, Ferreira Silva HB, Rios R, et al. The anti-allergic activity of Cymbopogoncitratus is mediated via inhibition of nuclear factor kappa B (Nf-Kb) activation. BMC Complement Altern Med 2015;15:168-182

27 McKay DL, Blumberg JB. A review of the bioactivity and potential health benefits of chamomile tea (Matricariarecutita L.). Phytother Res 2006;20(7):519-530

28 Arruda JT, Approbato FC, Maia MCS, Silva TM, Approbato MS. Efeito do extrato aquoso de camomila (Chamomillarecutita L.) na prenhez de ratas e no desenvolvimento dos filhotes. Rev Bras Plantas Med. 2013;15(1):66-71

29 Gonzales E, Iglesias I, Carretero E, Villar A. Gastric cytoprotection of bolivian medicinal plants. J Ethnopharmacol 2000;70(3): 329-333

30 Oliveira AC, Endringer DC, Amorim LA, das Graças L Brandão M, Coelho MM. Effect of the extracts and fractions of Baccharistrimera and Syzygiumcumini on glycaemia of diabetic and nondiabetic mice. J Ethnopharmacol 2005;102(3):465-469

31 Alonso J, Desmarchelier C. Plantas medicinalesautóctonas de la Argentina. Bases científicas para suaplicaciónenatención primaria de salud. Buenos Aires: LOLA; 2006

32 Pádua BdaC, Rossoni Júnior JV, Magalhães CL, et al. Protective effect of Baccharistrimera extract on acute hepatic injury in a model of inflammation induced by acetaminophen. MediatorsInflamm 2014;2014:196598

33 Ruiz ALTG, Taffarello D, Souza VHS, Carvalho JE. Farmacologia e toxicologia de Peumus boldus e Baccharisgenistelloides. Rev Bras Farmacogn. 2008;18(2):295-300

34 Grigoleit HG, Grigoleit P. Peppermint oil in irritable bowel syndrome. Phytomedicine 2005;12(8):601-606

35 Romero-Jiménez M, Campos-Sánchez J, Analla M, Muñoz-Serrano A, Alonso-Moraga A. Genotoxicity and anti-genotoxicity of some traditional medicinal herbs. Mutat Res 2005;585(1-2):147-155 